\title{
HSD17B1 expression induces inflammation-aided rupture of mammary gland myoepithelium
}

\author{
Päivi Järvensivu1,*, Taija Heinosalo1,*, Janne Hakkarainen', Pauliina Kronqvist ${ }^{2}$, Niina Saarinen ${ }^{1,+}$ and \\ Matti Poutanen ${ }^{1,+}$ \\ IInstitute of Biomedicine, Research Centre for Integrative Physiology and Pharmacology and Turku Center for Disease Modeling, University of Turku, \\ Turku, Finland \\ Institute of Biomedicine, Research Center for Cancer, Infections and Immunity, University of Turku and Department of Pathology, Turku University \\ Hospital, Turku, Finland
}

Correspondence should be addressed to M Poutanen or N Saarinen: matti.poutanen@utu.fi or niina.saarinen@utu.fi

*(P Järvensivu and T Heinosalo contributed equally to this work)

+ (N Saarinen and M Poutanen jointly supervised this work)

\begin{abstract}
Hydroxysteroid (17-beta) dehydrogenase type 1 (HSD17B1) converts low-active estrogen estrone to highly active estradiol. Estradiol is necessary for normal postpubertal mammary gland development; however, elevated estradiol levels increase mammary tumorigenesis. To investigate the significance of the human HSD17B1 enzyme in the mammary gland, transgenic mice universally overexpressing human HSD17B1 were used (HSD17B1TG mice). Mammary glands obtained from HSD17B1TG females at different ages were investigated for morphology and histology, and HSD17B1 activity and estrogen receptor activation in mammary gland tissue were assessed. To study the significance of HSD17B1 enzyme expression locally in mammary gland tissue, HSD17B1-expressing mammary epithelium was transplanted into cleared mammary fat pads of wild-type females, and the effects on mammary gland estradiol production, epithelial cells and the myoepithelium were investigated. HSD17B1TG females showed increased estrone to estradiol conversion and estrogen-response element-driven estrogen receptor signaling in mammary gland tissue, and they showed extensive lobuloalveolar development that was further enhanced by age along with an increase in serum prolactin concentrations. At old age, HSD17B1TG females developed mammary cancers. Mammary-restricted HSD17B1 expression induced lesions at the sites of ducts and alveoli, accompanied by peri- and intraductal inflammation and disruption of the myoepithelial cell layer. The lesions were shown to be estrogen dependent, as treatment with an antiestrogen, $\mathrm{ICI} 182,780$, starting when lesions were already established reversed the phenotype. These data elucidate the ability of human HSD17B1 to enhance estrogen action in the mammary gland in vivo and indicate that HSD17B1 is a factor inducing phenotypic alterations associated with mammary tumorigenesis.
\end{abstract}

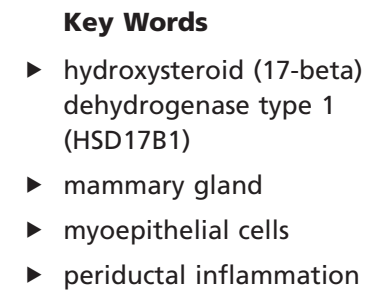

Endocrine-Related Cancer (2018) 25, 393-406 


\section{Introduction}

Postpubertal mammary gland development is extensively hormonally regulated, and 17-beta-estradiol (E2) is a hormone essential for normal postpubertal mammary gland development. In hormone-deprived mice, additive and sequential administration of E2 in concert with progesterone and prolactin in combination with cortisol and growth hormone can recapitulate mammary gland development (Nandi 1958, Brisken \& O'Malley 2010). Estrogen receptor alpha (ESR1) is expressed in both stromal and epithelial compartments of the mammary gland. E2 exerts its mammotropic effect mainly through epithelial ESR1, as demonstrated by mammary gland transplantation experiments. There was a complete lack of postpubertal ductal development in the ESR1-deficient mammary epithelium transplanted into mammary fat pads of wild-type (WT) female mice, whereas normal mammary gland development was observed for WT epithelium transplanted into mammary fat pads devoid of ESR1 (Mallepell et al. 2006).

The importance of estrogens in the etiology of human breast cancer is widely recognized. Prolonged lifetime estrogen exposure due to early menarche, late menopause, nulliparity, prolonged oral contraceptive use and hormone replacement therapy increases the risk of breast cancer, whereas pregnancy at younger age and breastfeeding are protective against breast cancer (Dall \& Britt 2017). Furthermore, an increased free E2 concentration in the plasma of postmenopausal women is associated with increased breast cancer risk (Yue et al. 2013), demonstrating a direct association between circulating estrogen levels and breast cancer risk. In experimental settings, E2 enhances mammary cancer development by triggering the neoplastic transformation of breast epithelial cells (Russo \& Russo 2006) and by inducing the proliferation and survival of ESR1-positive breast cancer cells (Frasor et al. 2003).

Hydroxysteroid (17-beta) dehydrogenase type 1 (HSD17B1) is an enzyme catalyzing the last steps of E2 biosynthesis together with CYP19A1 (Cytochrome P450 family 19 subfamily A member 1). CYP19A1, also known as aromatase, converts androstenedione and testosterone to estrone (E1) and E2, respectively, and HSD17B1 efficiently catalyzes the conversion of biologically low-active E1 to highly active E2 (Poutanen et al. 1993, Miettinen et al. 1996, Puranen et al. 1997, Day et al. 2008). Human HSD17B1 is mainly expressed in estrogen-producing tissues, the ovary (Tremblay et al. 1989, Ghersevich et al. 1994) and placenta (Fournet-Dulguerov et al. 1987) but is also expressed at lower levels in peripheral estrogen target tissues, such as the breast (Poutanen et al. 1992, Miettinen et al. 1999) and endometrium (Mäentausta et al. 1991, Dassen et al. 2007). In women, increased HSD17B1 expression has been reported in breast premalignant lesions, ductal carcinoma in situ and breast cancer (Poutanen et al. 1992, Sasano et al. 1996, Ariga et al. 2000, Oduwole et al. 2004, Sasaki et al. 2010). HSD17B2 is a counteracting enzyme for HSD17B1 that has been shown to convert highly potent E2 to less potent E1 and its expression is often lost in breast cancer cells (Luu-The et al. 1995, Miettinen et al. 1996). In epidemiological studies, increased HSD17B1 expression is linked to increased breast cancer risk. In women with ESR-positive breast cancer, high HSD17B1 expression is associated with late recurrence (Gunnarsson et al. 2001, 2005) and amplification of HSD17B1 decreases survival rates (Gunnarsson et al. 2003, 2008). Furthermore, patients with HSD17B1 expressing tumors have significantly shorter overall and diseasefree survival (Oduwole et al. 2004, Salhab et al. 2006). In addition to HSD17B1 expression alone, alterations in the $H S D 17 B 1$-to-HSD17B2 ratio modify breast cancer risk. In women with ESR-positive breast cancer, high HSD17B1to-HSD17B2 ratios are associated with worse prognosis and increase the risk for recurrence (Gunnarsson et al. $2001,2005)$. Respectively, high intratumoral HSD17B2 or high HSD17B2-to-HSD17B1 expression ratios are linked to improved prognosis and reduced risk of recurrence (Gunnarsson et al. 2001, 2005).

In healthy breast tissue of postmenopausal and premenopausal women, the serum E2 concentration is the major determinant of the intratissue E2 concentration (Depypere et al. 2015). Interestingly, in breast cancer patients, higher intratumoral E2 concentrations than those in the plasma are often reported (Geisler 2003, Stanczyk et al. 2015). The higher intratumoral E2 concentration is considered to be due to local intratumoral estrogen synthesis from circulating androgen precursors (Sasano et al. 2008). Together with aromatase and a few other reductive HSD17B enzymes, HSD17B1 is suggested to contribute to the maintenance of high intratumoral E2 levels (Miyoshi et al. 2001). In xenograft tumors derived from human ESR-positive breast cancer cells, HSD17B1 expression increases intratumoral E2 synthesis, and thus, increases the potency of E1 to stimulate tumor growth (Husen et al. 2006, Day et al. 2008). Similarly, increased HSD17B1 expression in tumor tissue is linked to increased intratumoral E2 levels in postmenopausal women (Sasano et al. 2006, Miki et al. 2009). These findings suggest that increased HSD17B1 
expression may contribute to the development of breast lesions and estrogen-responsive breast cancer.

In this study, we investigated the impact of HSD17B1 expression on mammary gland tissue by using transgenic mice with universal overexpression of human HSD17B1 (HSD17B1TG mice) (Saloniemi et al. 2007). We previously reported that HSD17B1TG mice have increased in vivo production of E2 from E1 (Saloniemi et al. 2010, Järvensivu et al. 2015) and that HSD17B1TG female mice develop a classical estrogen-induced endometrial hyperplasia phenotype, indicating enhanced estrogen action in estrogen target tissues. In the present study, we report HSD17B1-induced effects on the mammary gland both in HSD17B1TG female mice and in wild-type (WT) mice with local human HSD17B1 overexpression in the mammary gland induced by transplanting human HSD17B1-expressing mammary epithelium into WT mammary gland. Our findings elucidate the role of increased HSD17B1 expression in the process of mammary gland tumorigenesis.

\section{Animals, materials and methods}

\section{Experimental animals and timeline of studies}

Animal care and use were conducted in accordance with the Finnish Act on Animal Experimentation and with EU laws, guidelines and recommendations. The studies were approved by the National Animal Experiment Board of Finland (2007-01367, 2010-04888, 257/04.10.07/2013, $10605 / 04.10 .07 / 2016)$

The mice were housed under a 12-h light/darkness cycle at $21 \pm 1^{\circ} \mathrm{C}$, and they had free access to soy-free RM3 chow (Special Diet Service, Whitman Essex, UK) and tap water. The generation and maintenance of $\mathrm{FVB} / \mathrm{N}$ mice expressing human HSD17B1 under the chicken betaactin promoter (HSD17B1TG mice) have been previously described (Saloniemi et al. 2010, Järvensivu et al. 2015). Briefly, HSD17B1TG males from line 013 and WT females were bred together, and heterozygous HSD17B1TG female offspring were used in the studies. In addition, bi-transgenic ERELuc-HSD17B1TG mice carrying an estrogen-response element (ERE)-driven luciferase reporter gene (Lemmen et al. 2004) in the HSD17B1 genetic background were used for mammary gland estrogen activity assays ex vivo. The maintenance and genotyping of these mice have been previously described (Järvensivu et al. 2015). A summary timeline diagram of the mouse experiments and analyses performed is presented in Supplementary Fig. 1 (see section on supplementary data given at the end of this article).

\section{Histological and morphological analyses of mammary gland tissues}

For histological analysis, tissues were fixed in 10\% (v/v) formalin at room temperature for at least $24 \mathrm{~h}$. The tissues were dehydrated, embedded in paraffin, cut into $4-\mu \mathrm{m}$ thick sections and stained with hematoxylin and eosin. Slides were then scanned with a Pannoramic 250 Flash II digital slide scanner (3DHISTECH, Budapest, Hungary). For morphological analysis, the fourth inguinal mammary gland was removed, spread on a glass slide and fixed in Carnoy's fixative (acetic acid-ethanol) at $+4^{\circ} \mathrm{C}$. These mammary gland whole-mount slides were rinsed with ethanol and tap water and were stained with carminealum for 3-4 days. The stained slides were then dehydrated in a series of ethanol washes (70-100\% ethanol), cleared in xylene and finally mounted onto glass slides in Pertex (Histolab Products AB, Gothenburg, Sweden).

\section{Serum prolactin measurements}

Blood was collected by heart puncture under tribromoethanol (Avertin, Sigma-Aldrich or Alfa Aesar, Karlsruhe, Germany) terminal anesthesia $(600-1000 \mu \mathrm{L}$ of $2.5 \%(\mathrm{v} / \mathrm{v})$ solution i.p.) for serum measurements. Blood samples, stored at $+4^{\circ} \mathrm{C}$ for $24 \mathrm{~h}$, were separated for serum collection by centrifugation and further stored at $-20^{\circ} \mathrm{C}$. The serum prolactin concentration was measured by radioimmunoassay as previously described (Rulli et al. 2002).

\section{Determination of HSD17B1 activity in mammary gland in vivo}

HSD17B1 activity in vivo was determined in 4-monthold HSD17B1TG and WT females. Radioactive $\left[{ }^{3} \mathrm{H}\right]-\mathrm{E} 1$ (Perkin Elmer) dissolved in ethanol:saline (20:80 by vol.) was slowly injected i.v. ( $2.5 \mu \mathrm{L} / \mathrm{g}, 1.6 \mathrm{Mbq} /$ mouse) . Mice were terminally anesthetized with tribromoethanol (Avertin, $600-1000 \mu \mathrm{L}$ of $2.5 \%$ (v/v) solution i.p., SigmaAldrich or Alfa Aesar), and $15 \mathrm{~min}$ after $\left[{ }^{3} \mathrm{H}\right]$-E1 substrate injection, blood was withdrawn from the heart. After cervical dislocation of the mice, the mammary glands were dissected, snap-frozen in liquid nitrogen and stored at $-80^{\circ} \mathrm{C}$. The frozen tissues were homogenized by UltraTurrax in ice-cold $50 \mathrm{mM}$ Tris-HCl buffer ( $\mathrm{pH} 7.4)$ and were extracted twice with isopropyl ether. The ether was then 
evaporated to dryness at $+37^{\circ} \mathrm{C}$ under nitrogen flow. Then, the extracted steroids were redissolved in acetonitrile-water (48:52 by vol.) and separated with an HPLC apparatus (Waters 2695, Waters Corporation, Milford, MA, USA) equipped with a Nova-Pak C18 column $(3.9 \times 150 \mathrm{~mm}$; Waters Co.) and Nova-Pak C18 guard column (Waters Co.) with acetonitrile (Rathburn, Walkerburn, Scotland) water $(48 / 52 \mathrm{v} / \mathrm{v})$ as a mobile phase using a flow rate of $1.2 \mathrm{~mL} / \mathrm{min}$. The eluent was mixed on-line with scintillant (Ecoscint A, National Diagnostics, Atlanta, GA, USA), and the beta emission of separated steroids was counted on-line with a scintillation analyzer (Packard model 150TR; Perkin Elmer). HSD17B1 activity was based on the percentage of $\left[{ }^{3} \mathrm{H}\right]-\mathrm{E} 1$ converted to $\left[{ }^{3} \mathrm{H}\right]-\mathrm{E} 2$.

\section{Estrogen receptor activation in mammary gland tissue of HSD17B1TG mice}

Frozen tissues from ERELuc and ERELuc-HSD17B1TG mice were homogenized by Ultra-Turrax in $500 \mu \mathrm{L}$ of lysis buffer (25 mM Tris acetate (pH 7.8), $1 \mathrm{mM}$ EDTA, 10\% (v/v) glycerol, 1\% (v/v) Triton X-100, $2 \mathrm{mM}$ dithiothreitol and Complete Mini Proteinase Inhibitor (Roche Diagnostics)). The homogenate was centrifuged for $30 \mathrm{~min}$ at $1000 \mathrm{~g}$, and luciferase activity in the supernatant was determined by a luciferase assay kit (BioThema, Handen, Sweden) according to the manufacturer's instructions. Luminescence was measured with a Victor Multilabel Counter (Perkin Elmer) and the obtained luminescence values were normalized against the samples' protein concentrations, which were determined with a Pierce BCA Protein Assay Kit according to the manufacturer's instructions (Thermo Scientific).

\section{Mammary gland transplantations}

In transplantation experiments, 18- to 20-day-old WT female mice were used as hosts, and 18- to 20-day-old or 4- to 6-month-old HSD17B1TG and WT females were used as donors. The mice were preoperatively administered $0.15 \mathrm{mg} / \mathrm{kg}$ buprenorphine i.p. (Temgesic, Shering-Plough, Kenilworth, NJ, USA) and $5 \mathrm{mg} / \mathrm{kg}$ carprofen s.c. (Rimadyl, Pfizer, NY, USA) was administered as a postoperative analgesic. The developing mammary parenchyma of the host was removed under isoflurane anesthesia by clearing the fat pad between nipples 4 and 5 and the inguinoabdominal lymph node from both right and left side mammary glands. A piece of mammary epithelium from an HSD17B1TG donor was transplanted into the right side, and WT epithelium was transplanted into the left side of the remaining host mammary fat pads. Postoperative analgesia was continued for 3 days with daily buprenorphine $(0.15 \mathrm{mg} / \mathrm{kg}$ i.p.) and carprofen $(5 \mathrm{mg} / \mathrm{kg}$, s.c.) injections. The transplanted hosts were killed 4 months $(n=21)$ or 17-18 months $(n=8)$ later with $\mathrm{CO}_{2}$ asphyxiation. After cervical dislocation of the mice, the transplanted mammary glands were collected, divided into three parts and processed for histological and morphological analyses and RNA expression analyses as described below.

\section{HSD17B1 activity measurement in tissues ex vivo and analysis of human HSD17B1 expression}

HSD17B1 activity in HSD17B1TG and WT-transplanted mammary glands was analyzed by measuring the conversion of $\left[{ }^{3} \mathrm{H}\right]-\mathrm{E} 1$ to $\left[{ }^{3} \mathrm{H}\right]-\mathrm{E} 2$. Tissues were homogenized in $10 \mathrm{mM} \mathrm{KH}_{2} \mathrm{PO}_{4}$ (pH 7.5) containing $1 \mathrm{mM}$ EDTA supplemented with protease inhibitor cocktail (Complete Mini, Roche Diagnostics GmbH), 0.01\% (v/v) BSA and 10\% (v/v) glycerol. Protein concentrations of the homogenates were determined by using a Pierce BCA Protein Assay Kit (Thermo Scientific) according to the manufacturer's instructions. Five micrograms of protein were mixed with $\left[{ }^{3} \mathrm{H}\right]-\mathrm{E} 1$ (Perkin Elmer); final $\left[{ }^{3} \mathrm{H}\right]-\mathrm{E} 1$ concentration in the reaction $6.3 \mathrm{nM}$ and $1.4 \mathrm{mM} \mathrm{NADPH}$, and the reaction was incubated at $37^{\circ} \mathrm{C}$ for $40 \mathrm{~min}$. Steroids were extracted from samples twice with diethyl ether (Merck) and redissolved into 48\% (v/v) acetonitrile in water, and $\left[{ }^{3} \mathrm{H}\right]-\mathrm{E} 1$ conversion to $\left[{ }^{3} \mathrm{H}\right]-\mathrm{E} 2$ was analyzed with an HPLC equipped with a scintillation counter as described earlier.

Analysis of human HSD17B1 expression in transplanted mammary glands was measured by quantitative RT-qPCR as previously described (Saloniemi et al. 2007) in triplicate reactions.

\section{Immunohistochemistry}

Paraffin-embedded mammary glands were cut into $4 \mu \mathrm{m}$ sections. The sections were deparaffinized and rehydrated in xylene and ethanol series. Antigen retrieval was performed in $10 \mathrm{mM}$ citrate buffer ( $\mathrm{pH}$ 6.0) in a pressure cooker or in $10 \mathrm{mM}$ TRIS-EDTA-buffer, except that for cytokeratin 19 (KRT19) and calponin (CNN1) antibodies $\mathrm{pH} 9.0$ was used for antigen retrieval. The endogenous peroxidase was then blocked by incubating the sections in $3 \%(\mathrm{v} / \mathrm{v}) \mathrm{H}_{2} \mathrm{O}_{2}$ for $20 \mathrm{~min}$, and then, the slides were incubated overnight at $+4^{\circ} \mathrm{C}$ with one of the following primary antibodies: (1) rat anti-mouse Ki-67 (clone TEC-3, 1:500 dilution, Dako), (2) mouse anti-human ESR1 (1D5, 1:100, Dako), (3) rabbit anti-human progesterone receptor (PGR, A0098, 1:100, Dako), (4) rabbit anti-human keratin 5 
(KRT5, RM-2106, 1:100, Thermo Scientific), (5) mouse anti-human alpha actin (ACTA2, sc-32251, 1:1000, Santa Cruz Biotechnology), (6) rabbit monoclonal anti-human cytokeratin 19 (KRT19, $1 \mathrm{~h}$ incubation at RT, Clone EPR1579Y, 1:500, Epitomics, Burlingame, CA, USA), (7) rabbit monoclonal anti-human calponin (CNN1, Clone EP798Y, 1:2000, Epitomics) or (8) mouse anti-humanHSD17B1 ( $1 \mu \mathrm{g} / \mathrm{mL}$, developed in our group) antibody. The primary antibodies were detected by using an anti-mouse or anti-rabbit Dako Envision+ system (Dako). Visualization was made with $\mathrm{DAB}+$ substrate (Dako). All sections were counterstained with Mayer's hematoxylin and scanned with a Pannoramic 250 Flash II digital slide scanner (3DHISTECH). For Ki-67 quantitation, over 200 mammary epithelial cells from different fields were counted, and the labeling index was calculated as the percentage of positive cells over the total number of cells counted. The epithelial expression of ESR1 and PGR was assessed according to the Allred scoring method (Allred et al. 1998).

\section{ESR antagonist and HSD17B1 inhibitor treatment}

Five-month-old host female mice with contralateral mammary tissues grafted with WT or HSD17B1TG epithelium at the age of 3 weeks were treated s.c. with $17 \mathrm{mg} / \mathrm{kg}$ the ESR antagonist ICI 182,780 (Fulvestrant, Selleckhem, Houston, TX, USA), hereafter referred to as ICI, twice a week or with $10 \mathrm{mg} / \mathrm{kg}$ the HSD17B1 inhibitor EC-15 (compound 21 in Messinger et al. 2009 provided by Forendo Pharma Ltd., Turku, Finland) once a day for 4 consecutive weeks. The selected dose of ICI was effective in our earlier studies with estrogen-responsive mouse mammary cancer (N Saarinen, unpublished observations). Then the mice were killed and mammary gland tissues were collected for morphological analysis and for analysis of the mammary KRT19-positive epithelial cell Ki-67 proliferation index. A subgroup of mice in the ICI treatment group was also treated with $5 \mathrm{mg} / \mathrm{kg}$ carprofen (Rimadyl), which did not affect the lesion phenotype. Thus, for the final data analysis, data obtained from ICI and ICI + carprofen-treated mice were combined.

\section{Statistical analyses}

All statistical analyses were performed with GraphPad Prism, version 7.02 for Windows. The statistical difference between the two groups was determined by Student's $t$-test or by Mann-Whitney $U$ test for normally and not normally distributed data, respectively. For multiple comparisons, one-way ANOVA followed by Tukey's post hoc test or
Kruskal-Wallis one-way ANOVA of ranks followed by Dunn's multiple comparisons test was performed for normally and not normally distributed data, respectively. Differences were considered statistically significant at $P<0.05$. Data are expressed as the mean \pm standard error of the mean (s.E.M.).

\section{Results \\ HSD17B1TG females show a mammary gland phenotype resembling that in pregnancy and present with increased incidence of mammary cancer}

The effect of life-long HSD17B1 overexpression on the adult mammary gland phenotype was initially investigated in female HSD17B1TG mice and age-matched WT mice as controls. At the age of 4 months, the HSD17B1TG mammary duct lumens were enlarged and filled with secretion, in contrast to wild-type (WT) female mice presenting ducts with small lumens devoid of secretion (Fig. 1A). At the age of 10 months, HSD17B1TG females showed enhanced alveolar development accompanied by ducts filled with a milk-like secretion and lipid-filled droplets resembling the mammary phenotype observed at mid-pregnancy (Fig. 1B). The lactating mammary phenotype was further enhanced in 18-month-old female HSD17B1TG mice (Fig. 1C). Furthermore, by the age of 18 months, three of six HSD17B1TG females had developed mammary tumors, while no tumors were observed in WT mice of a similar age. Some of the tumors developed histopathological features resembling those of grade I or II human ductal carcinoma (Fig. 1C). Inflammatory cells were observed in the tumor tissues in parallel with the lactating phenotype (Fig. 1C). In HSD17B1TG mice, unlike in WT mice, serum prolactin concentrations were increased with aging, and the highest concentrations were measured in 12-monthold-mice (Fig. 1D). The HSD17B1TG mice developed pituitary adenomas (data not shown) that likely explain the increased circulating prolactin concentrations.

\section{Estrogenicity is increased in HSD17B1TG female mammary gland tissue}

To investigate the impact of HSD17B1 expression on HSD17B1 activity in mammary gland tissue in vivo, E1 was injected into the tail veins of HSD17B1TG and WT female mice, and the formed E2 was measured in the mammary gland tissue. In HSD17B1TG female mammary tissue, a significant proportion (57-85\%) of the administered E1 was present as E2, while in WT mammary tissue, only $6-11 \%$ of the E1 provided was converted to E2 (Fig. 2A). 
A
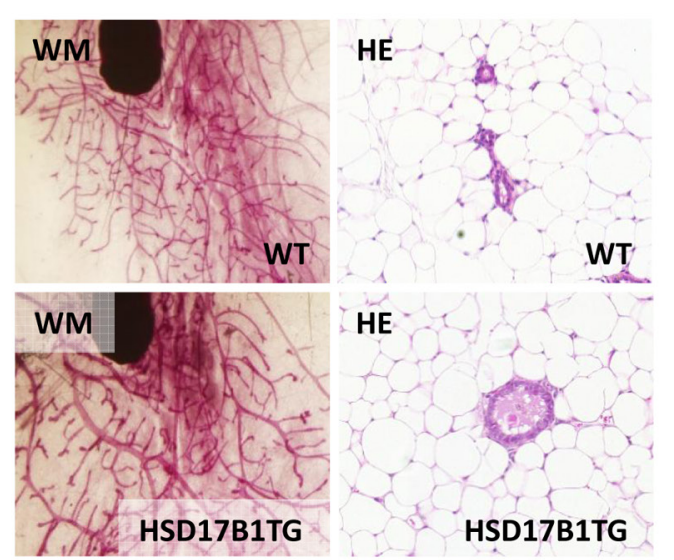

C
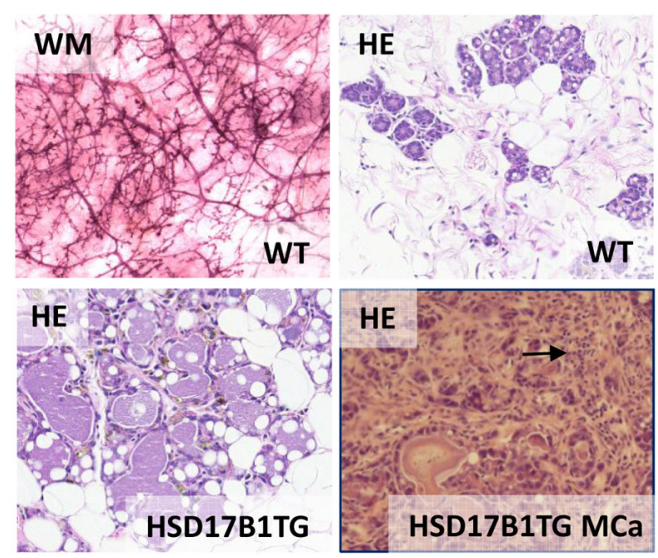

B

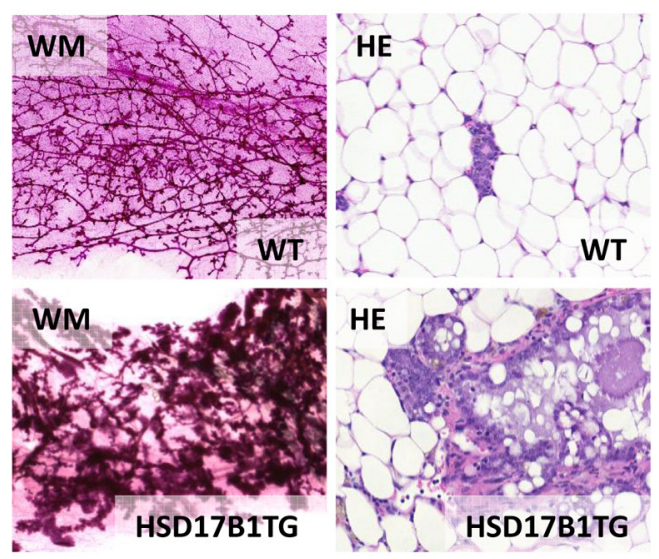

D

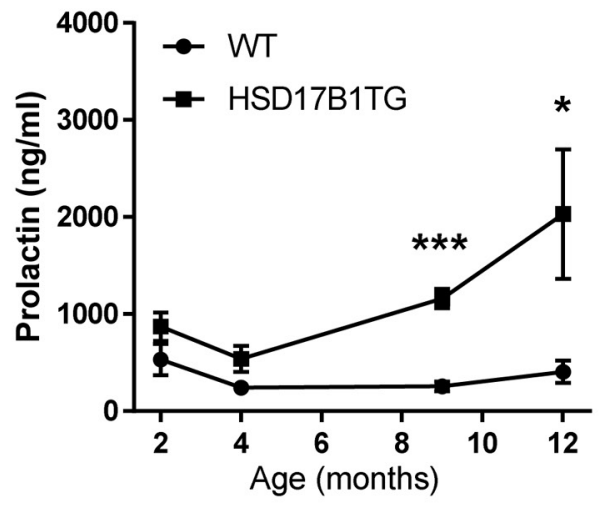

Figure 1

Morphology of mammary glands of wild-type (WT) and transgenic female mice expressing human HSD17B1 (HSD17B1TG). Representative whole-mount (WM) and hematoxylin-eosin (HE) staining of WT and HSD17B1TG mammary glands at the age of (A) 4 months and (B) 10 months. (C) Representative whole-mount (WM) and hematoxylin-eosin (HE) staining in WT mammary glands and mammary and mammary cancer (MCa) histology in HSD17B1TG female mice at the age of 18 months. Inflammatory cells in MCa are indicated with an arrow. (D) Serum prolactin levels of transgenic HSD17B1expressing (HSD17B1TG) female mice. Each time point represents data obtained from 4 to 8 mice. Statistical differences between groups were determined by Kruskal-Wallis one-way ANOVA of ranks followed by Dunn's multiple comparisons test. ${ }^{*} P<0.05 .{ }^{*} * *<0.001$.

The impact of HSD17B1 expression on mammary tissue estrogenicity in vivo was further investigated in ERELuc reporter mice and in ERELuc-HSD17B1TG mice. HSD17B1 expression significantly increased the ERELuc reporter activity in mammary gland tissue (Fig. 2B), indicating increased ESR activity in the tissue in vivo.

\section{Mammary gland-restricted HSD17B1 expression induces the formation of mammary lesions, epithelial cell proliferation and intratissue estradiol production}

The impact of mammary-specific HSD17B1 expression on mammary gland morphology was investigated in WT female mice with contralateral inguinoabdominal mammary fat pads bearing mammary ductal epithelium transplanted from WT or HSD17B1TG donors. The analysis of whole mounts collected 4 months after mammary epithelial engraftment revealed lesions at the sites of ducts and alveoli in mammary glands originating from the HSD17B1TG mice, while no lesion formation was observed in WT-transplanted glands (Fig. 3A). Histopathological analyses of the mammary glands with lesions indicated massive intra- and periductal inflammation surrounding the ducts at the sites of lesions, while such inflammatory cell infiltration around parenchyma developed from WT epithelium was not observed (Fig. 3A). Furthermore, no lactation phenotype in WT or HSD17B1TG mammary gland was observed (Fig. 3A). As expected, marked HSD17B1 mRNA expression 
A

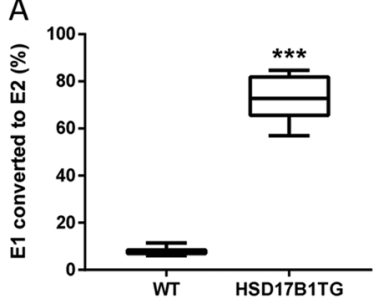

B

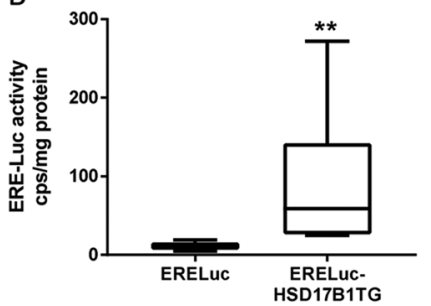

Figure 2

HSD17B1 expression increases the estrogenicity in mammary glands of HSD17B1TG female mice. (A) Percentages of estrone (E1) and estradiol (E2) in mammary gland in vivo in wild-type (WT) and HSD17B1TG mice. (B) Estrogen receptor reporter (ERELuc) activity in mammary tissue of ERELuc mice and ERELUC-HSD17B1TG mice at the age of 4 months. Boxplots indicate the median and the lower and upper quartiles. Whiskers indicate the maximum and minimum. Blots represent data from 3 to 6 mice per group. Statistical differences between the two groups were determined by Student's $t$-test. $* * P<0.01$. ${ }^{* * * P} P<0.001$.

was measured in the mammary glands with HSD17B1TG epithelium, which resulted in a strongly increased capacity of the tissue to produce E2 from E1 ex vivo (Fig. 3B and $\mathrm{C}$ ). However, a local increase in $\mathrm{E} 2$ production capacity in HSD17B1-expressing mammary gland did not alter the uterine weight compared to uterine weight of WT mice, indicating no significant change in systemic E2 levels (Fig. 3D). Along with the increased capacity for E2 production, a significantly increased proportion of cells positive for a proliferation marker, Ki-67, was observed in
HSD17B1-expressing mammary epithelial cells compared to WT epithelial cells (Fig. 4A and B). However, ESR1 and PGR expression levels were similar in the transplanted HSD17B1TG and WT mammary epithelium (Fig. 4A, C and D). Despite the increased epithelial cell proliferation, mammary gland tumors did not form after mammary gland transplantation within the 18-month follow-up period (data not shown), suggesting that HSD17B1 alone is not sufficient for tumor formation.

\section{HSD17B1-driven periductal mastitis is associated with disruption of the luminal epithelial cell layer and with the breakdown of continuous myoepithelium}

The structures of the HSD17B1-induced lesions were further studied with immunohistochemical analysis of epithelial and basal/myoepithelial cell markers. The expression pattern of the luminal epithelial cell marker KRT19 and basal/myoepithelial cell markers KRT5, CNN1 and ACTA2 revealed an association between HSD17B1induced periductal inflammation and focal disruption of epithelial luminal and myoepithelial cell layers at the site of inflammatory cell infiltration (Fig. 5). At the sites of a broken or absent myoepithelial cell layer (Fig. 5B, C and D), the luminal epithelial cells were disorganized and devoid of polarity (Fig. 5A).
A

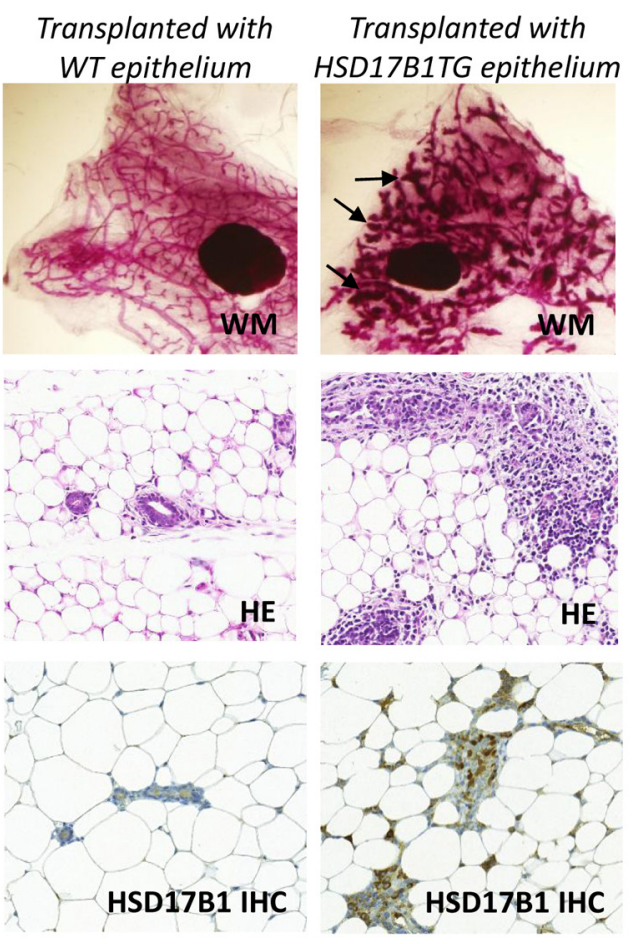

B

C

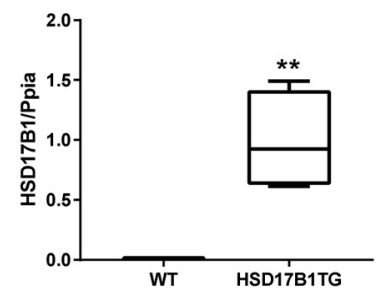

D
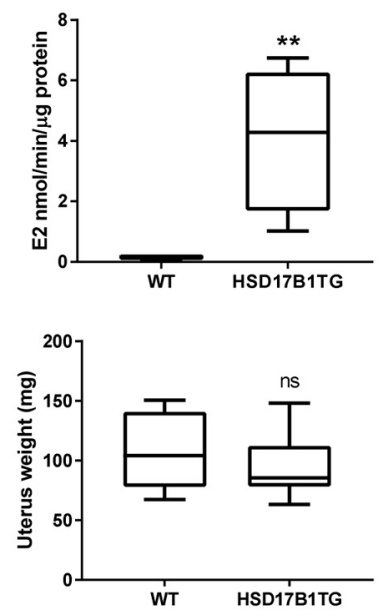

Figure 3

Local human HSD17B1 expression in mammary epithelium induces the formation of lymphocyteassociated lesions, increases the conversion of estrone (E1) to estradiol (E2) in the mammary tissue but does not affect wild-type (WT) host uterine weight, a biomarker of estrogenicity. (A) Representative whole-mount (WM), hematoxylineosin (HE) and HSD17B1 immunohistochemical (IHC) staining of mammary glands transplanted with WT or HSD17B1-expressing (HSD17B1TG) mammary epithelium. Some lesions in WM of HSD17B1TG mammary gland are indicated with arrows. (B) Human HSD17B1 mRNA expression in mammary gland transplanted with WT or HSD17B1TG mammary epithelium ( $n=4$ in both groups). (C) HSD17B activity measured ex vivo as the conversion of E1 to E2 in mammary tissue with WT $(n=5)$ or HSD17B1TG $(n=6)$ mammary epithelium. (D) The uterine weight of intact WT mice $(n=5)$ and WT mice transplanted with HSD17B1TG mammary gland epithelium $(n=21)$. All samples for analyses were collected 4 months after the transplantations. Boxplots indicate the median and the lower and upper quartiles. Whiskers indicate the maximum and minimum. Statistical differences between the two groups were determined by Student's $t$-test. ${ }^{*} P<0.01$. $n s$, non-significant. 
A
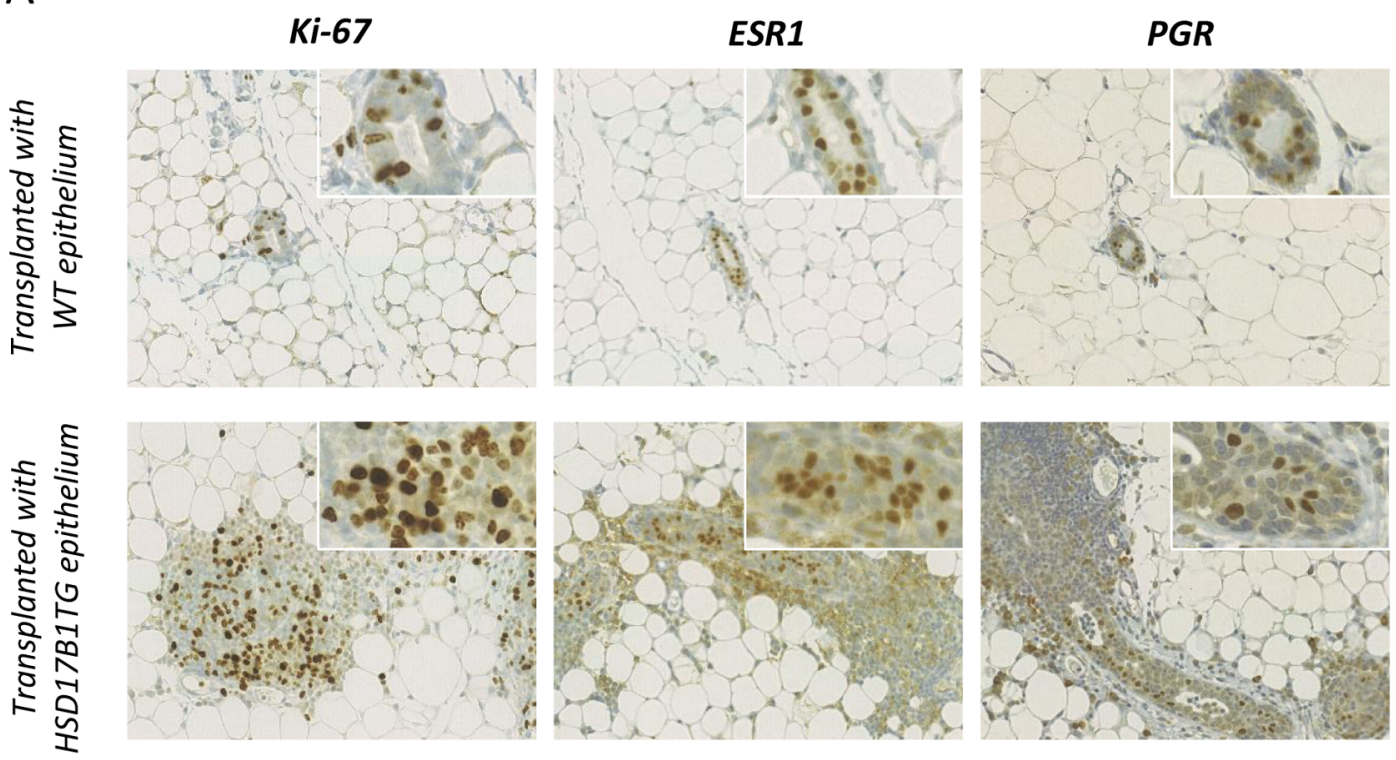

B

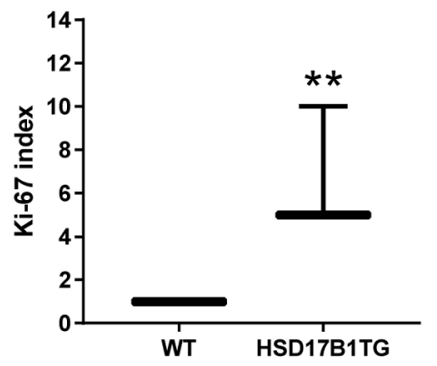

C

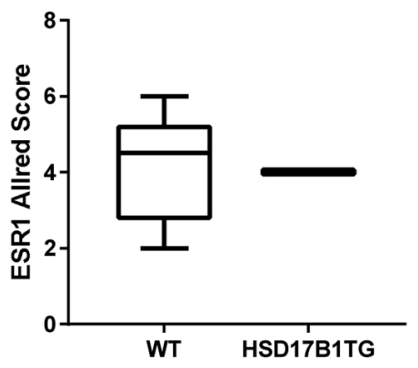

D

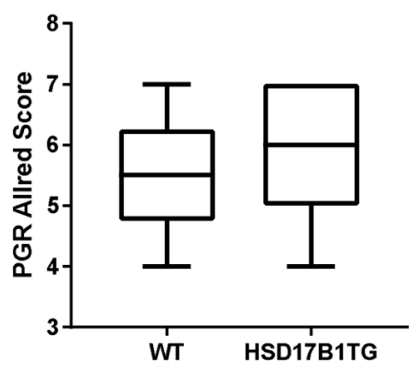

\section{Figure 4}

Local human HSD17B1 expression in mammary gland induces epithelial proliferation. (A) Expression of Ki-67, estrogen receptor alpha (ESR1) and progesterone receptor (PGR) in mammary glands transplanted with wild-type (WT) or transgenic HSD17B1-expressing (HSD17B1TG) mammary epithelium. Samples were collected 4 months after the transplantation. (B) Ki-67 index in mammary epithelial cells (positivity in WT-transplanted gland was set to one in each mouse). (C) Allred score of ESR1 and (D) PGR expression in mammary epithelium of WT and HSD17B1TG transplanted glands. Boxplots indicate the median and the lower and upper quartiles. Whiskers indicate the maximum and minimum. Blots represent data from 3 to 7 mice per group. Statistical difference between WT and HSD17B1TG groups was determined by Student's $t$-test. ** $P<0.01$.

\section{Downregulation of ESR signaling rescues the mammary gland lesion phenotype}

The role of estrogen signaling in HSD17B1-induced inflammatory lesions was investigated by treating the mammary gland-transplanted mice with the antiestrogen ICI or with the HSD17B1 inhibitor EC-15 starting 4 months after transplantation, i.e., starting at the time point when mammary gland lesions were already established (Fig. 3A). Interestingly, the ICI treatment reversed the established lesions, which was observed as a significant reduction in lesion number accompanied by significant rescue of the histological phenotype, while HSD17B1 inhibitor treatment tended to rescue the phenotype, but the effect did not reach statistical significance (Fig. 6A). Accordingly, the ICI treatment significantly reduced mammary epithelial cell proliferation, while epithelial cell proliferation in vehicle- and HSD17B1 inhibitortreated mice was similar (Fig. 6B). These data indicate that HSD17B1-induced inflammation-associated mammary gland lesions are dependent on ESR signaling and thus are reversible with ESR antagonist treatment.

\section{Discussion}

In this study, we show that HSD17B1 overexpression induces mammary cancer in transgenic mice. Furthermore, we demonstrate that in WT mice with mammary gland-specific 


\section{Transplanted with WT epithelium}

A

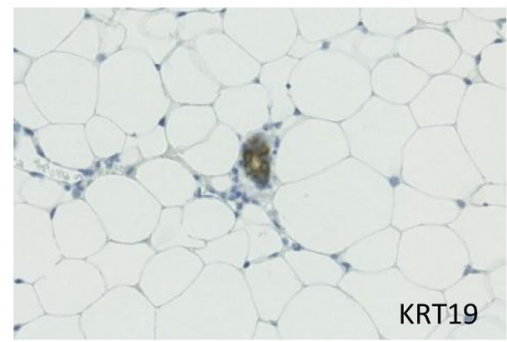

B

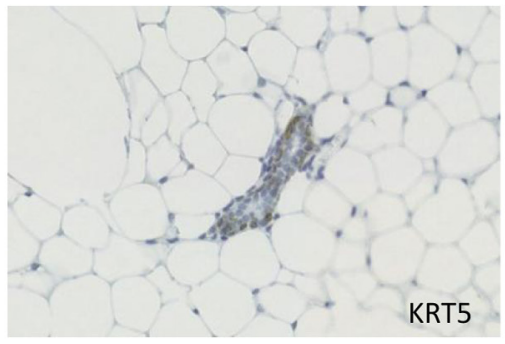

C

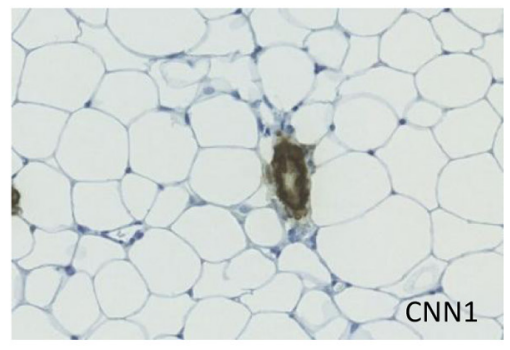

D

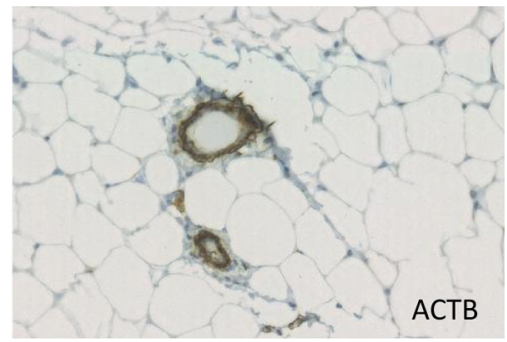

Transplanted with HSD17B1TG epithelium
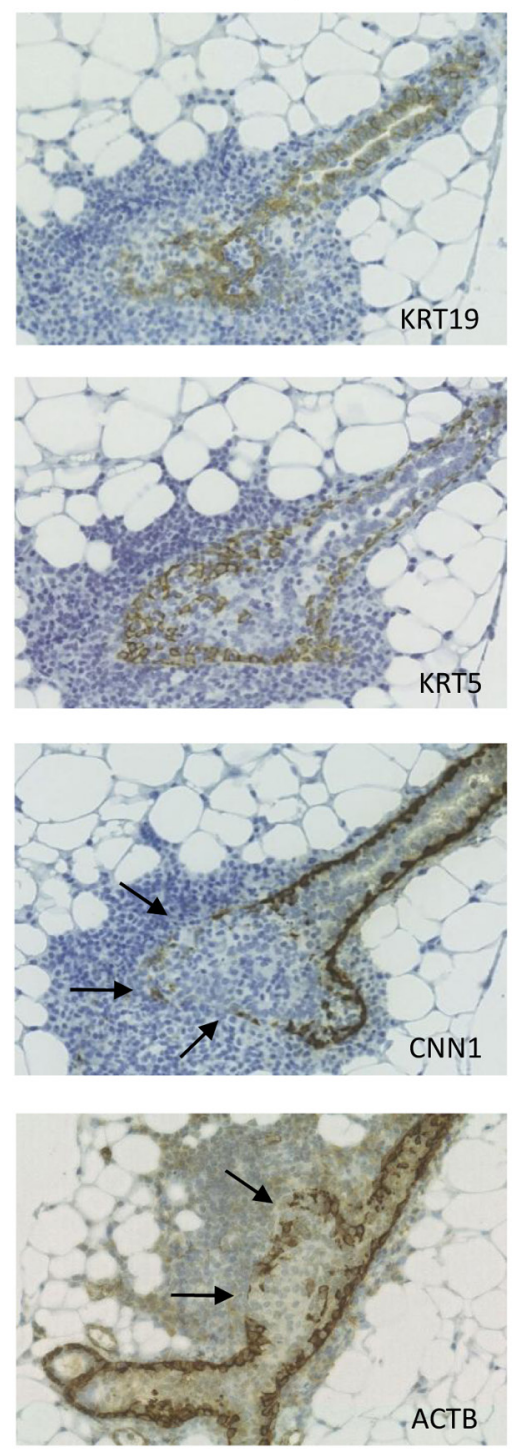

Figure 5

Local HSD17B1 expression in mammary epithelium induces inflammation-assisted breakage of the myoepithelial layer. (A) Keratin 19 (KRT19), (B) keratin 5 (KRT5), (C) calponin (CNN1) and (D) alpha actin (ACTA2) immunohistochemistry in mammary glands transplanted with wild-type (WT) or transgenic HSD17B1 expressing (HSD17B1TG) mammary epithelium. Samples were collected 4 months after mammary epithelial transplantations.
HSD17B1 expression, there are responses that are considered relevant for breast carcinogenesis. More specifically, HSD17B1 increases epithelial cell proliferation and ESR signaling in the mammary gland in vivo, which is due to increased intratissue production of E2 from its circulating precursor E1. Similar factors, i.e., increased breast epithelial proliferation (Huh et al. 2016), altered ESR signaling (Huang et al. 2015) and increased $\mathrm{E} 2$ concentrations (Yue et al. 2013) are linked to increased breast cancer risk in women. We also demonstrate that in mammary gland tissue, HSD17B1 expression leads to infiltration of inflammatory cells into the ductal stroma, where destruction of the myoepithelial cell layer at the sites of inflammation was observed. These types of tissue responses have not yet been described in the context of HSD17B1 and the mammary gland. However, in women, both periductal inflammation and coincident loss of myoepithelium have been described (Man \& Sang 2004) and are considered carcinogenesis-promoting responses for breast tumorigenesis (Polyak \& Kalluri 2010, Yeong et al. 2017). Thus, our current findings support the role of HSD17B1 as a factor contributing to mammary tumorigenesis.

In healthy pre- and postmenopausal women, the serum and breast tissue estrogen profiles are similar (Depypere et al. 2015). Interestingly, in breast cancer, the tissue estrogen profile differs from the serum profile (Geisler 2003, Stanczyk et al. 2015), and the enzymes expressed locally in the cancer tissue are thought to be 
A

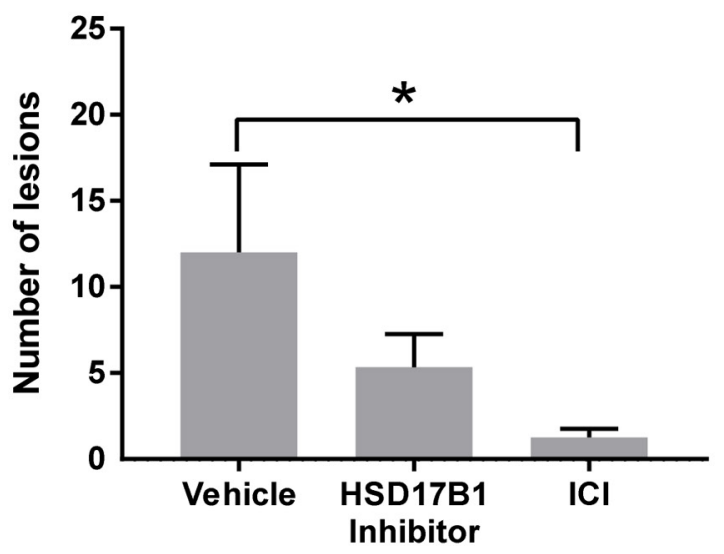

B

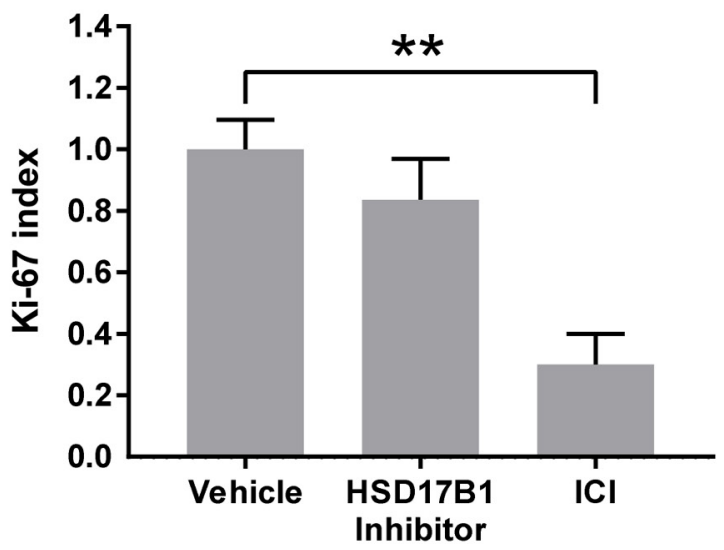

C
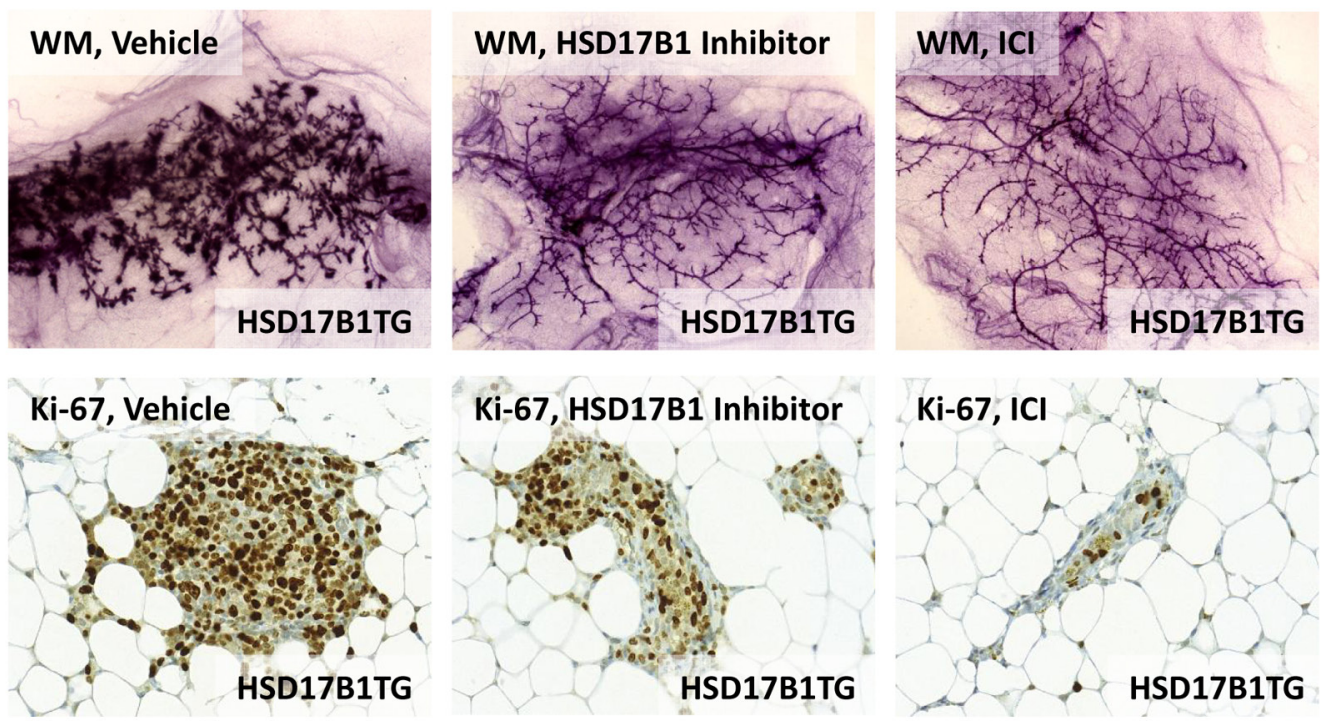

Figure 6

Antiestrogen treatment reduces mammary lesion number and epithelial proliferation. (A) Number of lesions counted from the mammary whole mounts after the treatments. (B) Mammary epithelial cell proliferation index after the treatments. The proliferation in HSD17B1-expressing mammary epithelium in vehicle-treated mice was set to 1. (C) Representative figures of mammary gland whole mounts (WM) and Ki-67 proliferation marker staining after the treatments. For the study, female WT host mice with one HSD17B1-expressing mammary parenchyma were treated with HSD17B1 inhibitor daily or with $\mathrm{ICI} 182,780$ (ICI) twice a week for 4 consecutive weeks starting 4 months after the cleared mammary fat pads of 18-20-day-old WT female mice were transplanted with HSD17B1TG donor epithelium (i.e., starting at the time point when mammary gland lesions were already established). The bars represent data obtained from 11 to 18 mice. Statistical differences between the groups were determined by one-way ANOVA followed by Tukey's post hoc test. ${ }^{*} P<0.05 . * * P<0.01$. Data are expressed as the mean \pm S.E.M.

responsible for steroid accumulation in cancer tissue. The steroid-metabolizing enzymes aromatase, estrone sulfatase and certain HSD17Bs, such as HSD17B1, HSD17B7 and HSD17B12, are suggested to control local estrogen production in breast cancer tissues by converting circulating androgen and estrogen precursors to active forms with high affinity to steroid receptors (Poutanen et al. 1992, Laplante et al. 2009, Shehu et al. 2011). However, the catalytic efficacy of HSD17B1 for the conversion of E1 to E2 is markedly higher (Puranen et al. 1997) than that of HSD17B7 or HSD17B12 (Törn et al. 2003, Luu-The et al. 2006), and even relatively low HSD17B1 expression levels in peripheral tissues are sufficient for E2 production (Delvoux et al. 2014). In the present study, we demonstrate that $\mathrm{E} 1$ administered into the blood circulation of HSD17B1TG mice via i.v. injection or used as a substrate ex vivo was efficiently converted to E2 in the mammary gland tissue, supporting HSD17B1 expression as a significant determinant of the mammary gland intratissue E2 concentration. 
Local expression of estrogen-producing enzymes in the mammary gland tissue is also linked to mammary tumorigenesis. In a study conducted with MMTVaromatase transgenic female mice, local aromatase expression in the mammary gland increased mammary tissue E2 concentrations and induced the development of mammary gland abnormalities, such as epithelial hyperplasia and ductal dysplasia (Tekmal et al. 1999, Diáz-Cruz et al. 2011). Importantly, in our current study, increased mammary gland-restricted HSD17B1 expression, along with increased E2 production capacity, induced the development of preneoplastic lesions in the mammary gland. The lesions were ameliorated by blocking ESR signaling with ICI, known to be an effective and full ESR antagonist in mouse mammary gland (Silberstein et al. 1994). This indicated that the lesions were dependent on ESR signaling. We previously reported that HSD17B1-induced imbalances in sex steroid hormones were linked to the formation of preneoplastic changes in other estrogen target tissues, such as the ovary and endometrium (Saloniemi et al. 2007, 2010). In HSD17B1TG females, we showed the formation of benign ovarian serous cystadenomas and endometrial hyperplasia (Saloniemi et al. 2007, 2010) that are known to predispose patients to ovarian and endometrial cancer, respectively. However, no ovarian or endometrial cancers were detected within the 18-month-long follow-up period (Saloniemi et al. 2007, 2010). Similarly, no mammary cancers were established in this study in mice with mammary gland-restricted HSD17B1 expression. These findings indicate that HSD17B1 expression and increased sex steroid exposure alone are not sufficient to induce tumorigenesis in reproductive tissues.

Prolactin is an essential hormone required for alveologenesis and for the differentiation of mammary epithelial cells into milk-producing cells (Nandi 1958, Brisken \& O'Malley 2010). Therefore, lactation phenotype of mammary gland is considered as a biological marker for systemic prolactin exposure in ovary-intact female mice. HSD17B1TG mice with advanced age showed increased lobuloalveolar development and lactating phenotype with a coincident increase in circulating prolactin levels. Thus, the increased circulating prolactin is a likely explanatory factor for the lactating mammary gland phenotype. However WT female mice bearing mammary fat pads with transplanted HSD17B1TG epithelium or WT mammary epithelium showed no lactation phenotype indicating that the local or systemic prolactin levels were not affected in transplanted mice. Increased circulating prolactin levels and sustained prolactin signaling are linked to increased risk of breast cancer (Tworoger et al. 2008, Fernandez et al. 2010). Accordingly in experimental rodent models, hyperprolactinemia induced in mice either by ectopic pituitary grafts or by overexpression of human chorionic gonadotropin induce the development of cancer in mammary glands (Huseby et al. 1985, Rulli et al. 2002). Mammary tumorigenesis induced by hyperprolactinemia in combination with estrogen is considered more relevant for human breast carcinogenesis than prolactin alone (Tworoger et al. 2008). In a previous study, the importance of co-operation with prolactin and E2 in mammary tumorigenesis was demonstrated in transgenic mice with mammary-targeted prolactin expression (Arendt et al. 2009). In those mice, the exposure to E2 together with endogenous prolactin decreased mammary tumor latency compared to mice exposed to prolactin alone, indicating that $\mathrm{E} 2$ enhances the prolactin-induced mammary gland neoplastic process. HSD17B1TG females with an increased circulating prolactin concentration and enhanced capacity for intratissue E2 production developed mammary cancers with 50\% penetrance during the 18-month-long follow-up period, while no cancers were observed in WT mice. Consequently, increased prolactin and E2 production are supposed factors inducing mammary cancer in HSD17B1TG female mice. In rodents, increase in systemic E2 is known to cause pituitary adenomas and prolactiomas, shown by us (Rulli et al. 2002) and others (Elias et al. 1984). In HSD17B1TG mice, HSD17B1 is expressed in pituitary gland (Saloniemi et al. 2007) and, thus, local E2 synthesis from its precursor E1 in the pituitary gland is possible. Therefore, we cannot distinguish the difference between paracrine and endocrine effect of E2 as a causal factor for pituitary adenomas observed in HSD17B1TG female mice. Interestingly, the HSD17B1-induced mammary tumors had histological similarities to human breast cancer, unlike prolactin-induced mammary cancers in general. This finding suggests that overexpression of HSD17B1 may contribute to the development of mammary cancers with a clinically relevant histotype.

In the normal mammary gland, myoepithelial cells positioned between the luminal cells and the basement membrane maintain the basement membrane, mediate luminal epithelial cell polarity and contribute to branching and differentiation processes (Man \& Sang 2004, Brisken \& O'Malley 2010, Polyak \& Kalluri 2010). At early stages of mammary tumorigenesis, myoepithelial cells provide a barrier preventing the invasion of cancerous epithelial cells into the surrounding stroma. Therefore, loss of myoepithelial cell layer integrity and the consequent loss 
of basal membrane are crucial events for carcinogenesis (Man \& Sang 2004, Yeong et al. 2017). In clinical ductal carcinoma in situ samples, most specimens with a focally disrupted myoepithelial cell layer are reported to display increased leucocyte infiltration and increased proliferation of epithelial cells at the site of the disrupted myoepithelium (Man \& Sang 2004). Interestingly, similar myoepitheliumrelated changes, i.e., a focally disrupted myoepithelial cell layer coincident with leucocyte infiltration and increased luminal epithelial cell proliferation, were observed in this study in mice with mammary gland-restricted HSD17B1 expression. Normal estrus cycle is likely an important factor driving peri- and intraductal inflammation and myoepithelial breakage as that phenotype was not observed in HSD17B1TG females that are devoid of estrus cycle (Saloniemi et al. 2010). Moreover, in a previous in vitro study, HSD17B1 expression was linked to increased tumorigenic potential of the human mammary-derived premalignant epithelial cell lines (Fu et al. 2010). These data suggest that HSD17B1 expression in mammary epithelium induces phenomena that are similar to those identified to be critical at early phases of mammary carcinogenesis. Whether a comparable association between the expression of HSD17B1 and mammary tumorigenesis occurs in clinical specimens remains to be explored.

In conclusion, this is the first in vivo evidence that increased human HSD17B1 expression in mammary gland epithelium (1) enhances the conversion of E1 to E2 in mammary gland tissue, (2) increases luminal epithelial cell proliferation and (3) induces the formation of mammary gland lesions. These lesions display focal disruption of the myoepithelial cell layer, a phenomenon co-existent with peri- and intraductal lymphocyte infiltration. Treatment with an estrogen receptor antagonist, ICI, ameliorates the ductal phenotype, indicating an estrogen receptor-dependent mechanism for lesion development. Furthermore, ubiquitous HSD17B1 expression present in HSD17B1TG mice induces mammary cancer with a histotype also found in human breast cancer. These data enlighten the impact of HSD17B1 expression in the mammary gland and indicate its importance in phenomena related to mammary tumorigenesis in vivo.

\section{Supplementary data}

This is linked to the online version of the paper at https://doi.org/10.1530/ ERC-17-0476.

\section{Declaration of interest}

The authors declare that there is no conflict of interest that could be perceived as prejudicing the impartiality of the research reported.

\section{Funding}

This work was supported by the Academy of Finland (\#277624), Sigrid Juselius Foundation, University of Turku Graduate School Drug Research Doctoral Programme - DRDP, Finnish Cultural Foundation, Varsinais-Suomi Regional Fund and The Finnish Funding Agency for Innovation, TEKES (\#598/31/2015).

\section{Acknowledgements}

Forendo Pharma Ltd. is acknowledged for providing the HSD17B1 inhibitor. Turku Center for Disease Modeling (TCDM) personnel are acknowledged for their skillful assistance.

\section{References}

Allred DC, Harvey JM, Berardo M \& Clark GM 1998 Prognostic and predictive factors in breast cancer by immunohistochemical analysis. Modern Pathology 11 155-168.

Arendt LM, Evans LC, Rugowski DE, Garcia-Barchino MJ, Rui H \& Schuler LA 2009 Ovarian hormones are not required for PRL-induced mammary tumorigenesis, but estrogen enhances neoplastic processes. Journal of Endocrinology 203 99-110. (https://doi. org/10.1677/JOE-09-0221)

Ariga N, Moriya T, Suzuki T, Kimura M, Ohuchi N, Satomi S \& Sasano H 200017 beta-Hydroxysteroid dehydrogenase type 1 and type 2 in ductal carcinoma in situ and intraductal proliferative lesions of the human breast. Anticancer Research 20 1101-1108.

Brisken C \& O'Malley B 2010 Hormone action in the mammary gland Cold Spring Harbor Perspectives in Biology 2 a003178. (doi:10.1101/ cshperspect.a003178)

Dall GV \& Britt KL 2017 Estrogen effects on the mammary gland in early and late life and breast cancer risk. Frontiers in Oncology 7110 (doi:10.3389/fonc.2017.00110)

Dassen H, Punyadeera C, Kamps R, Delvoux B, Van Langendonckt A, Donnez J, Husen B, Thole H, Dunselman G \& Groothuis P 2007 Estrogen metabolizing enzymes in endometrium and endometriosis. Human Reproduction 22 3148-3158. (https://doi.org/10.1093/humrep/ dem310)

Day JM, Foster PA, Tutill HJ, Parsons MF, Newman SP, Chander SK, Allan GM, Lawrence HR, Vicker N, Potter BV, et al. 2008 17betahydroxysteroid dehydrogenase Type 1 , and not Type 12 , is a target for endocrine therapy of hormone-dependent breast cancer. International Journal of Cancer 122 1931-1940. (https://doi. org/10.1002/ijc.23350)

Delvoux B, D’Hooghe T, Kyama C, Koskimies P, Hermans RJ, Dunselman GA \& Romano A 2014 Inhibition of type 1 $17 \beta$-hydroxysteroid dehydrogenase impairs the synthesis of $17 \beta$-estradiol in endometriosis lesions. Journal of Clinical Endocrinology and Metabolism 99 276-284. (https://doi.org/10.1210/ jc.2013-2851)

Depypere HT, Bolca S, Bracke M, Delanghe J, Comhaire F \& Blondeel P 2015 The serum estradiol concentration is the main determinant of the estradiol concentration in normal breast tissue. Maturitas $\mathbf{8 1}$ 42-45. (https://doi.org/10.1016/j.maturitas.2015.01.014)

Díaz-Cruz ES, Sugimoto Y, Gallicano GI, Brueggemeier RW \& Furth PA 2011 Comparison of increased aromatase versus ER $\alpha$ in the generation of mammary hyperplasia and cancer. Cancer Research $\mathbf{7 1}$ 5477-5487. (https://doi.org/10.1158/0008-5472.CAN-10-4652)

Elias KA \& Weiner RI 1984 Direct arterial vascularization of estrogeninduced prolactin-secreting anterior pituitary tumors. PNAS 81 4549-4553. (https://doi.org/10.1073/pnas.81.14.4549)

Fernandez I, Touraine P \& Goffin V 2010 Prolactin and human tumourogenesis. Journal of Neuroendocrinology 22 771-777. (https:// doi.org/10.1111/j.1365-2826.2010.02011.x) 
Fournet-Dulguerov N, MacLusky NJ, Leranth CZ, Todd R, Mendelson CR, Simpson ER \& Naftolin F 1987 Immunohistochemical localization of aromatase cytochrome P-450 and estradiol dehydrogenase in the syncytiotrophoblast of the human placenta. Journal of Clinical Endocrinology and Metabolism 65 757-764. (https://doi.org/10.1210/ jcem-65-4-757)

Frasor J, Danes JM, Komm B, Chang KC, Lyttle CR \& Katzenellenbogen BS 2003 Profiling of estrogen up- and downregulated gene expression in human breast cancer cells: insights into gene networks and pathways underlying estrogenic control of proliferation and cell phenotype. Endocrinology $1444562-4574$. (https://doi.org/10.1210/en.2003-0567)

Fu J, Weise AM, Falany JL, Falany CN, Thibodeau BJ, Miller FR, Kocarek TA \& Runge-Morris M 2010 Expression of estrogenicity genes in a lineage cell culture model of human breast cancer progression. Breast Cancer Research and Treatment 120 35-45. (https:// doi.org/10.1007/s10549-009-0363-8)

Geisler J 2003 Breast cancer tissue estrogens and their manipulation with aromatase inhibitors and inactivators. Journal of Steroid Biochemistry and Molecular Biology 86 245-253. (https://doi. org/10.1016/S0960-0760(03)00364-9)

Ghersevich SA, Poutanen MH, Martikainen HK \& Vihko RK 1994 Expression of 17 beta-hydroxysteroid dehydrogenase in human granulosa cells: correlation with follicular size, cytochrome P450 aromatase activity and oestradiol production. Journal of Endocrinology 143 139-150. (https://doi.org/10.1677/joe.0.1430139)

Gunnarsson C, Olsson BM, Stål O \& Southeast Sweden Breast Cancer Group 2001 Abnormal expression of 17beta-hydroxysteroid dehydrogenases in breast cancer predicts late recurrence. Cancer Research 61 8448-8451.

Gunnarsson C, Ahnström M, Kirschner K, Olsson B, Nordenskjöld B, Rutqvist LE, Skoog L \& Stål O 2003 Amplification of HSD17B1 and ERBB2 in primary breast cancer. Oncogene 22 34-40. (https://doi. org/10.1038/sj.onc.1206078)

Gunnarsson C, Hellqvist E \& Stål O 2005 17beta-Hydroxysteroid dehydrogenases involved in local oestrogen synthesis have prognostic significance in breast cancer. British Journal of Cancer 92 547-552. (https://doi.org/10.1038/sj.bjc.6602375)

Gunnarsson C, Jerevall PL, Hammar K, Olsson B, Nordenskjöld B, Jansson A \& Stål O 2008 Amplification of HSD17B1 has prognostic significance in postmenopausal breast cancer. Breast Cancer Research and Treatment 108 35-41. (https://doi.org/10.1007/s10549-0079579-7)

Huang B, Warner M \& Gustafsson JÅ 2015 Estrogen receptors in breast carcinogenesis and endocrine therapy. Molecular and Cellular Endocrinology 418 240-244. (https://doi.org/10.1016/j. mce.2014.11.015)

Huh SJ, Oh H, Peterson MA, Almendro V, Hu R, Bowden M, Lis RL, Cotter MB, Loda M, Barry WT, et al. 2016 The proliferative activity of mammary epithelial cells in normal tissue predicts breast cancer risk in premenopausal women. Cancer Research 76 1926-1934. (https://doi.org/10.1158/0008-5472.CAN-15-1927)

Huseby RA, Soares MJ \& Talamantes F 1985 Ectopic pituitary grafts in mice: hormone levels, effects on fertility, and the development of adenomyosis uteri, prolactinomas, and mammary carcinomas. Endocrinology 116 1440-1448. (https://doi.org/10.1210/endo-116-4-1440)

Husen B, Huhtinen K, Saloniemi T, Messinger J, Thole HH \& Poutanen M 2006 Human hydroxysteroid (17-beta) dehydrogenase 1 expression enhances estrogen sensitivity of MCF-7 breast cancer cell xenografts. Endocrinology 147 5333-5339. (https://doi.org/10.1210/ en.2006-0778)

Järvensivu P, Saloniemi-Heinonen T, Awosanya M, Koskimies P, Saarinen N \& Poutanen M 2015 HSD17B1 expression enhances estrogen signaling stimulated by the low active estrone, evidenced by an estrogen responsive element-driven reporter gene in vivo.
Chemico Biological Interactions 234 126-134. (https://doi. org/10.1016/j.cbi.2015.01.008)

Laplante Y, Rancourt C \& Poirier D 2009 Relative involvement of three 17beta-hydroxysteroid dehydrogenases (types 1, 7 and 12) in the formation of estradiol in various breast cancer cell lines using selective inhibitors. Molecular and Cellular Endocrinology $\mathbf{3 0 1}$ 146-153. (https://doi.org/10.1016/j.mce.2008.08.026)

Lemmen JG, Arends RJ, van Boxtel AL, van der Saag PT \& van der Burg B 2004 Tissue- and time-dependent estrogen receptor activation in estrogen reporter mice. Journal of Molecular Endocrinology 32 689-701. (https://doi.org/10.1677/jme.0.0320689)

Luu-The V, Zhang Y, Poirier D \& Labrie F 1995 Characteristics of human types 1, 2 and 317 beta-hydroxysteroid dehydrogenase activities: oxidation/reduction and inhibition. Journal of Steroid Biochemistry and Molecular Biology 55 581-587. (https://doi.org/10.1016/09600760(95)00209-X)

Luu-The V, Tremblay P \& Labrie F 2006 Characterization of type 12 17beta-hydroxysteroid dehydrogenase, an isoform of type $317 \mathrm{beta}$ hydroxysteroid dehydrogenase responsible for estradiol formation in women. Molecular Endocrinology 20 437-443. (https://doi. org/10.1210/me.2005-0058)

Mallepell S, Krust A, Chambon P \& Brisken C 2006 Paracrine signaling through the epithelial estrogen receptor alpha is required for proliferation and morphogenesis in the mammary gland. PNAS 103 2196-2201. (https://doi.org/10.1073/pnas.0510974103)

Man YG \& Sang QX 2004 The significance of focal myoepithelial cell layer disruptions in human breast tumor invasion: a paradigm shift from the 'protease-centered' hypothesis. Experimental Cell Research 301 103-118. (https://doi.org/10.1016/j.yexcr.2004.08.037)

Messinger J, Husen B, Koskimies P, Hirvelä L, Kallio L, Saarenketo P \& Thole H 2009 Estrone C15 derivatives - a new class of 17betahydroxysteroid dehydrogenase type 1 inhibitors. Molecular and Cellular Endocrinology 301 216-224. (https://doi.org/10.1016/j. mce.2008.10.022)

Miettinen MM, Mustonen MV, Poutanen MH, Isomaa VV \& Vihko RK 1996 Human 17 beta-hydroxysteroid dehydrogenase type 1 and type 2 isoenzymes have opposite activities in cultured cells and characteristic cell and tissue-specific expression. Biochemical Journal 314 839-845. (https://doi.org/10.1042/bj3140839)

Miettinen M, Mustonen M, Poutanen M, Isomaa V, Wickman M, Söderqvist G, Vihko R \& Vihko P 1999 17Beta-hydroxysteroid dehydrogenases in normal human mammary epithelial cells and breast tissue. Breast Cancer Research and Treatment 57 175-182. (https://doi.org/10.1023/A:1006217400137)

Miki Y, Suzuki T \& Sasano H 2009 Intracrinology of sex steroids in ductal carcinoma in situ (DCIS) of human breast: comparison to invasive ductal carcinoma (IDC) and non-neoplastic breast. Journal of Steroid Biochemistry and Molecular Biology 114 68-71. (https://doi. org/10.1016/j.jsbmb.2008.12.021)

Miyoshi Y, Ando A, Shiba E, Taguchi T, Tamaki Y \& Noguchi S 2001 Involvement of up-regulation of 17beta-hydroxysteroid dehydrogenase type 1 in maintenance of intratumoral high estradiol levels in postmenopausal breast cancers. International Journal of Cancer 94 685-689. (https://doi.org/10.1002/ijc.1525)

Mäentausta O, Sormunen R, Isomaa V, Lehto VP, Jouppila P \& Vihko R 1991 Immunohistochemical localization of 17 beta-hydroxysteroid dehydrogenase in the human endometrium during the menstrual cycle. Laboratory Investigations 65 582-587.

Nandi S 1958 Endocrine control of mammary-gland development in the C3H/He Crgl mouse. Journal of National Cancer Institute 21 1039-1063. (https://doi.org/10.1093/jnci/21.6.1039)

Oduwole OO, Li Y, Isomaa VV, Mäntyniemi A, Pulkka AE, Soini Y \& Vihko PT 2004 17beta-hydroxysteroid dehydrogenase type 1 is an independent prognostic marker in breast cancer. Cancer Research 64 7604-7609. (https://doi.org/10.1158/0008-5472.CAN-04-0446)
(C) 2018 Society for Endocrinology Published by Bioscientifica Ltd. Printed in Great Britain 
Polyak K \& Kalluri R 2010 The role of the microenvironment in mammary gland development and cancer. Cold Spring Harbour Perspectives in Biology 2 a003244. doi:10.1101/cshperspect.a003244.

Poutanen M, Isomaa V, Lehto VP \& Vihko R 1992 Immunological analysis of 17 beta-hydroxysteroid dehydrogenase in benign and malignant human breast tissue. International Journal of Cancer $\mathbf{5 0}$ 386-390. (https://doi.org/10.1002/ijc.2910500310)

Poutanen M, Miettinen M \& Vihko R 1993 Differential estrogen substrate specificities for transiently expressed human placental 17 beta-hydroxysteroid dehydrogenase and an endogenous enzyme expressed in cultured COS-m6 cells. Endocrinology 133 2639-2644. (https://doi.org/10.1210/endo.133.6.8243287)

Puranen T, Poutanen M, Ghosh D, Vihko P \& Vihko R 1997 Characterization of structural and functional properties of human 17 beta-hydroxysteroid dehydrogenase type 1 using recombinant enzymes and site-directed mutagenesis. Molecular Endocrinology 11 77-86. (https://doi.org/10.1210/mend.11.1.9872)

Rulli SB, Kuorelahti A, Karaer O, Pelliniemi LJ, Poutanen M \& Huhtaniemi I 2002 Reproductive disturbances, pituitary lactotrope adenomas, and mammary gland tumors in transgenic female mice producing high levels of human chorionic gonadotropin. Endocrinology 143 4084-4095. (https://doi.org/10.1210/en.2002220490)

Russo J \& Russo IH 2006 The role of estrogen in the initiation of breast cancer. Journal of Steroid Biochemistry and Molecular Biology 102 89-96. (https://doi.org/10.1016/j.jsbmb.2006.09.004)

Salhab M, Reed MJ, Al Sarakbi W, Jiang WG \& Mokbel K 2006 The role of aromatase and 17-beta-hydroxysteroid dehydrogenase type 1 mRNA expression in predicting the clinical outcome of human breast cancer. Breast Cancer Research and Treatment 99 155-162. (https://doi.org/10.1007/s10549-006-9198-8)

Saloniemi T, Lamminen T, Huhtinen K, Welsh M, Saunders P, Kujari H \& Poutanen M 2007 Activation of androgens by hydroxysteroid (17beta) dehydrogenase 1 in vivo as a cause of prenatal masculinization and ovarian benign serous cystadenomas. Molecular Endocrinology 21 2627-2636. (https://doi.org/10.1210/me.2007-0144)

Saloniemi T, Järvensivu P, Koskimies P, Jokela H, Lamminen T, GhaemMaghami S, Dina R, Damdimopoulou P, Mäkelä S, Perheentupa A, et al. 2010 Novel hydroxysteroid (17beta) dehydrogenase 1 inhibitors reverse estrogen-induced endometrial hyperplasia in transgenic mice. American Journal of Pathology 176 1443-1451. (https://doi. org/10.2353/ajpath.2010.090325)

Sasaki Y, Miki Y, Hirakawa H, Onodera Y, Takagi K, Akahira J, Honma S, Ishida T, Watanabe M, Sasano H, et al. 2010 Immunolocalization of estrogen-producing and metabolizing enzymes in benign breast disease: comparison with normal breast and breast carcinoma. Cancer Science 101 2286-2292. (https://doi. org/10.1111/j.1349-7006.2010.01673.x)

Sasano H, Frost AR, Saitoh R, Harada N, Poutanen M, Vihko R, Bulun SE, Silverberg SG \& Nagura H 1996 Aromatase and 17 beta- hydroxysteroid dehydrogenase type 1 in human breast carcinoma. Journal of Clinical Endocrinology and Metabolism 81 4042-4046.

Sasano H, Suzuki T, Nakata T \& Moriya T 2006 New development in intracrinology of breast carcinoma. Breast Cancer 13 129-136. (https://doi.org/10.2325/jbcs.13.129)

Sasano H, Suzuki T, Miki Y \& Moriya T 2008 Intracrinology of estrogens and androgens in breast carcinoma. Journal of Steroid Biochemistry and Molecular Biology 108 181-185. (https://doi.org/10.1016/j. jsbmb.2007.09.012)

Stanczyk FZ, Mathews BW \& Sherman ME 2015 Relationships of sex steroid hormone levels in benign and cancerous breast tissue and blood: a critical appraisal of current science. Steroids 99 91-102. (https://doi.org/10.1016/j.steroids.2014.12.011)

Shehu A, Albarracin C, Devi YS, Luther K, Halperin J, Le J, Mao J, Duan RW, Frasor J \& Gibori G 2011 The stimulation of HSD17B7 expression by estradiol provides a powerful feed-forward mechanism for estradiol biosynthesis in breast cancer cells. Molecular Endocrinology 25 754-766. (https://doi.org/10.1210/me.2010-0261)

Silberstein GB, Van Horn K, Shyamala G \& Daniel CW 1994 Essential role of endogenous estrogen in directly stimulating mammary growth demonstrated by implants containing pure antiestrogens. Endocrinology 134 84-90. (https://doi.org/10.1210/ endo.134.1.8275973)

Tekmal RR, Kirma N, Gill K \& Fowler K 1999 Aromatase overexpression and breast hyperplasia, an in vivo model - continued overexpression of aromatase is sufficient to maintain hyperplasia without circulating estrogens, and aromatase inhibitors abrogate these preneoplastic changes in mammary glands. Endocrine-Related Cancer 6 307-314. (https://doi.org/10.1677/erc.0.0060307)

Tremblay Y, Ringler GE, Morel Y, Mohandas TK, Labrie F, Strauss JF 3rd \& Miller WL 1989 Regulation of the gene for estrogenic 17-ketosteroid reductase lying on chromosome 17cen----q25. Journal of Biological Chemistry 264 20458-20462.

Tworoger SS \& Hankinson SE 2008 Prolactin and breast cancer etiology: an epidemiologic perspective. Journal of Mammary Gland Biology and Neoplasia 13 41-53. (https://doi.org/10.1007/s10911-008-9063-y)

Törn S, Nokelainen P, Kurkela R, Pulkka A, Menjivar M, Ghosh S, CocaPrados M, Peltoketo H, Isomaa V \& Vihko P 2003 Production, purification, and functional analysis of recombinant human and mouse 17beta-hydroxysteroid dehydrogenase type 7. Biochemical and Biophysical Research Communications 305 37-45. (https://doi. org/10.1016/S0006-291X(03)00694-6)

Yeong J, Thike AA, Tan PH \& Iqbal J 2017 Identifying progression predictors of breast ductal carcinoma in situ. Journal of Clinical Pathology 70 102-108. (https://doi.org/10.1136/ jclinpath-2016-204154)

Yue W, Yager JD, Wang JP, Jupe ER \& Santen RJ 2013 Estrogen receptordependent and independent mechanisms of breast cancer carcinogenesis. Steroids 78 161-70. (https://doi.org/10.1016/j. steroids.2012.11.001)

Received in final form 12 January 2018

Accepted 25 January 2018

Accepted Preprint published online 25 January 2018 (c) 2018 Society for Endocrinology Published by Bioscientifica Ltd. Printed in Great Britain 